\title{
PREDIKSI KASUS COVID-19 DI INDONESIA MENGGUNAKAN METODE BACKPROPAGATION DAN REGRESI LINEAR
}

\author{
Wahyudin $^{1}$, Heri Purwanto ${ }^{2}$ \\ Konsentrasi Teknik Informatika ${ }^{1,2}$ \\ Program Studi Manajemen Informatika ${ }^{1,2}$ \\ STMIK LPKIA Bandung ${ }^{1,2}$ \\ 160613056wahyudin@gmail.com ${ }^{1}$, herpurwanto@lpkia.ac.id ${ }^{2}$
}

\begin{abstract}
Abstrak: Kemunculan COVID-19 pertama kali menyerang manusia di Wuhan, China sedangkan di Indonesia sendiri mulai menyerang dalam lepas 2 Maret 2020 terdeteksi dua orang terkonfirmasi positif. Dari kasus tersebut tiap harinya mengalami pertambahan yang relatif signifikan. Virus corona menular dengan sangat cepat, oleh karena itu WHO atau Organisasi Kesehatan Dunia memutuskan virus COVID-19 menjadi pandemi lepas 11 Maret 2020. Virus corona melonjak dengan sangat cepat sehingga dibutuhkan penanggulanan segera mungkin. Virus corona bisa dengan gampang menyebar luas serta dapat menyerang manusia tanpa pandang usia. Melihat penyebaran virus yang sangat cepat ini akhirnya para pemerintah disebagian negara sudah menetapkan untuk memberlakukan lockdown. Hingga saat ini masih belum menemukan obat atau vaksin yang bisa digunakan untuk mengatasi penyebaran virus COVID-19. Adapun maksud dilakukannya penelitian ini yaitu untuk dapat memperkirakan jumlah kasus aktif pada penambahan kasus COVID-19 di Indonesia. Pada penelitian ini akan dicobakan dengan menggunakan metode Backpropagation dan Regresi Linear. Hasil prediksi kasus aktif dengan Backpropagation memberikan hasil penambahan dan penurunan yang tidak terlalu signifikan sedangkan hasil prediksi kasus aktif dengan Regresi Linear menunjukan bahwa penambahan kasus untuk tiap harinya mengalami penambahan kasus aktif.
\end{abstract}

Kata kunci: Prediksi; Data Mining; Backpropagation; Regresi Linear

\begin{abstract}
The emergence of COVID-19 first attacked humans in Wuhan, China, while in Indonesia itself, it began to attack on March 2, 2020 when two people were confirmed positive. From these cases every day has a relatively significant increase. The corona virus is spreading very quickly, therefore the WHO or the World Health Organization decided that the COVID-19s will become a pandemic off March 11, 2020. The corona virus is rising very fast, so immediate response is needed. The corona virus can easily spread and can attack humans regardless of age. Seeing the rapid spread of the virus, finally the governments of some countries have decided to impose a lockdown. Until now, we have not found a drug or vaccine that can be used to overcome the spread of the COVID-19 virus. The purpose of this research is to be able to estimate the number of active cases in the addition of COVID-19 cases in Indonesia. This research will be tried using Backpropagation and Linear Regression methods. The results of prediction of active cases with Backpropagation gave the results of additions and decreases that were not too significant, while the results of prediction of active cases with Linear Regression showed that the addition of cases for each day experienced an increase in active cases.
\end{abstract}

Keywords: Prediction; Data Mining; Backpropagation; Regresi Linear

DOI: $10.52362 /$ jisamar.v5i2.420

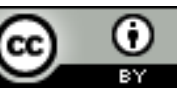

Ciptaan disebarluaskan di bawah Lisensi Creative Commons Atribusi 4.0 Internasional. 


\section{PENDAhUluaN}

Dunia untuk sekarang ini sedang siaga dengan maraknya penyebaran sebuah virus jenis baru yang kita ketahui yaitu virus corona. ( $\mathrm{CoV})$ atau Coronaviruses adalah salah satu bagian dari keluarga besar virus yang mengakibatkan beberapa penyakit seperti infeksi saluran pernapasan hingga penyakit yang cukup berat yaitu (MERS-CoV) atau Middle East Respiratory Syndrome and (SARS-CoV) atau Severe Acute Respiratory Syndrome. Virus corona merupakan virus jenis baru yang dijumpai di tahun 2019 dan sebelumnya tidak pernah diperkirakan akan menyerang manusia [1]. Kemunculan virus ini pertama kali menyerang di Wuhan, China sedangkan di Indonesia sendiri mulai menyerang dalam lepas 2 Maret 2020 terdeteksi dua orang terkonfirmasi positif Virus corona melonjak dengan sangat cepat sehingga dibutuhkan penanggulanan segera mungkin. Virus corona bisa dengan gampang menyebar luas serta dapat menyerang manusia tanpa pandang usia. Virus corona menular dengan sangat cepat, oleh karena itu WHO atau Organisasi Kesehatan Dunia memutuskan COVID-19 menjadi wabah atau pandemi lepas 11 Maret 2020. Dimana status pandemi ini mengindikasikan bahwa meluasnya penyebaran COVID-19 akan berlangsung secara drastis sampai diperkirakan hampir tidak terdapat negara-negara di dunia yang bisa lolos dari serangan virus corona [2].

Penularan COVID-19 ini dapat dengan mudah menular apabila berhubungan langsung dengan penderita. Namun sampai sekarang para ilmuan masih belum bisa menemukan obat khusus yang bisa digunakan untuk menyembukan kasus infeksi COVID-19. Melihat belum adanya obat yang dapat mengatasi virus inilah pemerintah di sebagian negara menetapkan untuk memberlakukan lockdown. Karantina berdasarkan UU RI Nomor 6 tahun 2018 mengenai Kekarantinaan Kesehatan merupakan restriksi aktivitas atau isolasi seseorang yang terjangkit penyakit menular seperti yang sudah diputuskan dalam aturan perundang-undangan walaupun belum menampakan tanda-tanda apapun dimaksudkan untuk pencegahan penyebaran terhadap orang yang berada di sekitarnya. Adapun sebagian negara yang sudah memberlakukan lockdown dalam upaya mencegah menyebarnya virus corona diantaranya yaitu Spanyol, China, Malaysia, dan Italia. Negara tersebut dari para pemerintahan menetapkan lockdown, penutupan seluruh akses baik dari fasilitas publik maupun transportasi. Dianjurkan para warga agar terus di rumah serta mengisolasi diri, diharapkan agar virus tidak semakin menyebar luas serta usaha penyembuhan bisa berjalan maksimal [3]. Sampai waktu ini belum ditemukan vaksin yang dapat dipakai untuk mengatasi penyebaran virus COVID-19. Masyarakat diharapkan agar tetap dirumah serta tidak keluar rumah terkecuali dalam keadaan darurat.

Berdasarkan dari kedua kasus tadi, kasus positif COVID-19 mengalami penambahan disetiap harinya. Penambahan kasus disetiap harinya belum bisa diprediksikan jumlahnya menjadikan penangganan seperti penyediaan layanan, fasilitas, dan tenaga medis belum bisa diperkirakan. Berdasarkan dari kasus tersebut, maka peneliti mencoba melakukan penelitian menggunakan Regresi Linier dan Backpropagation. Salah satu model penggunaan data diantaranya dengan analisis regresi. Analisis regresi yaitu contoh metode statistika yang cukup populer. Analisis regresi adalah cabang ilmu statistika yang digunakan untuk mengetahui interaksi antara 2 variabel, yaitu variabel tidak bebasdan variabel bebas. Dalam analisis regresi, tentu saja dibutuhkan data. Data adalah hal yang paling primer yang nantinya akan diolah sampai menghasilkan suatu konklusi berdasarkan apa yang diperkirakan pada awal penelitian.

Jaringan Syaraf Tiruan adalah sistem pemrosesan data yang cukup kuat yang bisa menangkap dan mewakili interaksi masukan-keluaran yang detail, dengan kemampuan untuk mengatasi masalah cukup mudah dipakai, kekuatan untuk menginput data kecepatan untuk mengeksekusi, dan menginisialisasikan sistem yang susah [4].

Pada penelitian ini dengan judul "Prediksi Kasus Covid-19 Di Indonesia Menggunakan Metode Backpropagation dan Fuzzy Tsukamoto" yang dialkukan oleh saudara Fra Siskus Dian Arianto dan Noviyanti P [5] membentuk sebuah contoh prediksi penambahan kasus Covid di Indonesia yaitu Model yang didapatkan dengan melakukan 1 kali percobaan arsitektur jaringan.

Dari latar belakang permasalahan yang telah dijelaskan pada uraian tadi maka bisa dirumuskan permasalahan sebagai berikut : bagaimana memprediksi penambahan kasus aktif virus corona dengan backpropagation dan regresi linear.

Berdasarkan dari rumusan masalah dan latar belakang yang sudah diuraikan, dimaksudkan tujuan penelitian ini adalah untuk dapat memperoleh model dalam memprediksi penambahan kasus COVID-19 di Indonesia serta untuk mengetahui seberapa besar angka penambahan kasus aktif dari metode yang digunakan yaitu backpropagation dan regresi linear.

DOI: $10.52362 / j i s a m a r . v 5 i 2.420$

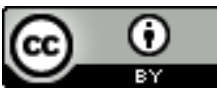

Ciptaan disebarluaskan di bawah Lisensi Creative Commons Atribusi 4.0 Internasional. 


\section{METODE}

\subsection{Pengumpulan Data}

Penelitian ini memakai data dari databooks yang terdiri dari atribut total kasus, kasus sembuh, kasus meninggal dan kasus aktif, pada penelitian ini hanya menggunakan data kasus aktif.

A. Pola input

Kasus aktif atau pola kasus aktif besok (mendatang) atau besar kasus aktif per hari, namun akan dibatasi hanya 15 hari. Data kasus aktif dari tanggal 1 s/d 15 Juni dan dari tanggal 1 s/d 15 Juli sebagai data latih, kemudian data kasus aktif dari tanggal 16 s/d 30 Juni dan dari tanggal 16 s/d 30 Juli sebagai data uji.

B. Pola output

Hasil keluaran yang diharapkan dari jaringan yaitu berupa perkiraan penambahan pada kasus mendatang atau banyaknya kasus per hari. Dalam hal ini akan digunakan jumlah neuron keluaran jaringan adalah 2 neuron.

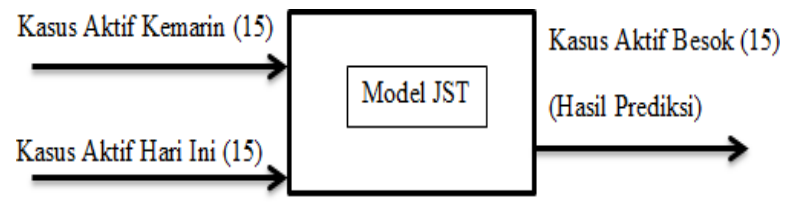

Gambar 1. Blok Diagram Model Jaringan Syaraf Tiruan

Tabel 1. Masukan dan Keluaran Model Jaringan Syaraf Tiruan

\begin{tabular}{l|l}
\hline & \multicolumn{1}{c}{ Keterangan } \\
\hline Masukan model JST() & $\begin{array}{l}\text { Data Kasus aktif kemarin, 15 neuron input } \\
\text { Data kasus aktif hari ini, 15 neuron input }\end{array}$ \\
\hline Keluaran model JST() & $\begin{array}{l}\text { Output dari model JST berupa banyaknya kasus aktif besok per } \\
\text { hari selama 15 hari, 15 neuron input }\end{array}$ \\
\hline
\end{tabular}

\subsection{Backpropagation dan Regresi Linear}

Penelitian ini menggunakan backpropagation dan regresi linear untuk memperoleh angka penambahan kasus aktif covid-19. Dalam metode backpropagation sendiri menggunakan beberapa fungsi pelatihan diantaranya yaitu traingd, traingdx dan traincgb yang nantinya akan dilihat hasil yang paling mendekati dengan data sebenarnya. Dalam metode regresi linear akan dicari apakah variabel hari (x) mempunyai pengaruh terhadap variabel (y) kasus aktif yang nantinya akan di validasi dengan menggunakan tabel coeficient.

\subsection{Evaluasi dan Validasi}

Dalam evaluasi dan validasi backpropagation agan digunakan tools matlab untuk memperoleh angka kasus penambahan kasus aktif dan dicari fungsi pelatihan yang hasil rata-rata error paling sedikit. Untuk evaluasi metode regresi linear akan diuji dengan menggunakan tools spss untuk melihat hasil keterkaitan antara variabel hari (x) dan variabel kasus aktif (y) kemudian di validasi menggunakan tabel coeficient.

\section{PEMBAHASAN DAN HASIL}

\subsection{Data Utama}

Data utama penelitian ini menggunakan data yang dikeluarkan oleh databooks yang terdiri dari atribut total kasus, kasus sembuh, kasus meninggal dan kasus aktif. Penelitian ini menggunakan kasus aktif atau pola kasus aktif besok (mendatang) atau besar kasus aktif per hari, namun akan dibatasi hanya 15 hari. Data kasus aktif dari tanggal $1 \mathrm{~s} / \mathrm{d} 15$ Juni dan dari tanggal $1 \mathrm{~s} / \mathrm{d} 15$ Juli sebagai data latih, kemudian data kasus aktif dari tanggal 16 s/d 30 Juni dan dari tanggal 16 s/d 30 Juli sebagai data uji.

DOI: $10.52362 /$ jisamar.v5i2.420

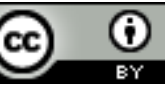

Ciptaan disebarluaskan di bawah Lisensi Creative Commons Atribusi 4.0 Internasional. 


\subsection{Hasil Penelitian}

Berdasarkan hasil penerapan mengunakan algoritma artificial neural network backpropagation dan regresi linear untuk memprediksi kasus covid-19 di Indonesia maka didapat hasil dari metode backpropagation:

1. Banyaknya data historis dari data kasus aktif yang dipakai untuk melatih jaringan syaraf tiruan akan membentuk tahap pengenalan terhadap pola kasus aktif menjadi lebih baik yang menyebabkan pada kemampuan pada JST dalam memperkirakan penambahan kasus aktif akan semakin baik.

2. Secara umum hasil prediksi kasus aktif dengan backpropagation memberikan hasil peningkatan dan penurunan yang tidak terlalu signifikan, parameter yang diinputkan dapat mempengaruhi kinerja dari algoritma backpropagation.

3. Berdasarkan hasil simulasi Matlab dengan tiga fungsi pelatihan yaitu traincgb didapatkan nilai rata-rata error yaitu sebesar 0,017107, dengan fungsi pelatihan traingd didapatkan nilai rata-rata error sebesar - 0,55116 serta fungsi pelatihan traingdx didapatkan nilai rata-rata error sebesar -3,82202 sehingga dapat disimpulkan fungsi pelatihan yang paling konvergen yaitu fungsi pelatihan terhadap traingdx dengan nilai rata-rata error paling kecil.

Hasil dari metode regresi:

1. Secara umum hasil prediksi kasus aktif dengan Regresi Linear menunjukan bahwa penambahan kasus untuk tiap harinya mengalami pertambahan kasus aktif.

2. Dari nilai signifikansi : berdasarkan tabel coeficient didapatkan value signifikansi sebanyak $0,185>0.05$, dari sini bisa dijelaskan bahwa variabel hari $\mathrm{X}$ berpengaruh (pengaruh negatif) terhadap variabel kasus aktif $\mathrm{Y}$.

3. Dari value $t$; diketahui nilai sebanyak $-1,401<2160$, maka bisa dijelaskan bahwa variabel hari $\mathrm{X}$ berpengaruh negatif terhadap variabel kasus aktif $Y$.

\subsection{Pembahasan}

Penerapan prediksi menggunakan backpropagation dengan fungsi pelatihan traingd, traingdx dan traincgb. Berdasarkan tabel contoh perhitungan menggunakan matlab yang ditunjukan pada tabel 1, dapat disimpulkan bahwa fungsi pelatihan traingdx lebih mendekati dengan kasus real dengan error rata-rata paling kecil.

Ditahap pengujian terhadap model jaringan dilakukan dengan meletakan arsitektur data baru yang sebelumnya belum dipakai di proses training. Kemudian data ini telah dipisahkan dari awal pada saat tahapan praproses data. Data yang dipakai ke jaringan adalah data kasus aktif dari tanggal 16 s/d 30 Juni dan dari tanggal 16 s/d 30 Juli sebagai data uji. Hasil atau output jaringan merupakan data 16 s/d 30 Agustus 2020 merupakan hasil perkiraan. Kemudiuan hasilnya dituangkan didalam bentuk statistik dan tabel sebagai berikut:

Tabel 2. Hasil Perhitungan Menggunakan Metode Backpropagation

\begin{tabular}{|c|c|c|c|c|c|c|c|}
\hline \multirow{2}{*}{ Waktu } & \multirow{2}{*}{ Kasus Aktif Real } & \multicolumn{3}{|c|}{ Prediksi JST } & \multicolumn{3}{c|}{ Error } \\
\cline { 3 - 8 } & & Traincgb & Traingd & Traingdx & Traingcgb & Traingd & Traingdx \\
\hline $16-8-2020$ & 40296 & 44233 & 39287 & 39865 & $-0,05769$ & 0,25991 & 0,11095 \\
\hline $17-8-2020$ & 40705 & 45921 & 39293 & 40149 & 0,064985 & 0,36382 & 0,14324 \\
\hline $18-8-2020$ & 40460 & 49536 & 39305 & 40586 & 0,016948 & 0,29755 & $-0,03256$ \\
\hline $19-8-2020$ & 39942 & 49115 & 39334 & 40682 & $-0,05611$ & 0,15652 & $-0,19083$ \\
\hline $20-8-2020$ & 40119 & 50946 & 39367 & 40737 & 0,055805 & 0,19355 & $-0,15947$ \\
\hline $21-8-2020$ & 39917 & 51605 & 39381 & 40745 & $-0,0042$ & 0,13786 & $-0,21358$ \\
\hline $22-8-2020$ & 39706 & 52249 & 39409 & 40606 & $-0,01489$ & 0,076347 & $-0,23197$ \\
\hline $23-8-2020$ & 39355 & 52608 & 39426 & 40398 & 0,016252 & 0,01842 & $-0,26893$ \\
\hline $24-8-2020$ & 37593 & 52943 & 39437 & 40142 & $-0,13521$ & $-0,47524$ & $-0,65693$ \\
\hline $25-8-2020$ & 38134 & 53010 & 39438 & 40232 & 0,10749 & $-0,33615$ & $-0,5408$ \\
\hline $26-8-2020$ & 37812 & 53060 & 39440 & 40199 & 0,048926 & $-0,41955$ & $-0,6151$ \\
\hline $27-8-2020$ & 37245 & 53238 & 39443 & 39948 & $-0,03469$ & $-0,56644$ & $-0,69659$ \\
\hline $28-8-2020$ & 37818 & 53357 & 39444 & 39692 & $-0,04842$ & $-0,419$ & $-0,48299$ \\
\hline $29-8-2020$ & 39132 & 53284 & 39443 & 39880 & 0,064767 & $-0,08037$ & $-0,19279$ \\
\hline $30-8-2020$ & 40525 & 53368 & 39444 & 39724 & $-0,00686$ & 0,27845 & 0,20633 \\
\hline
\end{tabular}

DOI: $10.52362 /$ jisamar.v5i2.420

Ciptaan disebarluaskan di bawah Lisensi Creative Commons Atribusi 4.0 Internasional. 
Penerapan prediksi menggunakan regresi linear ;

1. Data diperoleh darihttps://databoks.katadata.co.id/.

2. Jumlah sampel yang digunakan adalah 15 hari dari tanggal $16 \mathrm{~s} / \mathrm{d} 30$ Juli 2020.

3. Variabel penelitian : hari menjadi variabel (x) dan kasus aktif menjadi variabel (y).

\section{Variables Entered/Removed ${ }^{\mathrm{b}}$}

\begin{tabular}{|l|l|l|l|}
\hline Model & $\begin{array}{c}\text { Variables } \\
\text { Entered }\end{array}$ & $\begin{array}{c}\text { Variables } \\
\text { Removed }\end{array}$ & Method \\
\hline 1 & Hari $^{\text {a }}$ &. & Enter \\
\hline
\end{tabular}

a. All requested variables entered

b. Dependent Variable: Kasus Aktif

Gambar 2. Variables Entered

Keterangan :

Gambar diatas mengungkapkan mengenai variabel yang sudah dimasukkan dan metode yang dipakai. Dimana disini variabel yang diinput merupakan variabel Hari menjadi variabel Independent dan Kasus Aktif menjadi variabel Dependent kemudian metode yang dipakai yaitu metode Enter.

\section{Model Summary}

\begin{tabular}{|l|l|r|r|r|}
\hline Model & R & R Square & $\begin{array}{c}\text { Adjusted R } \\
\text { Square }\end{array}$ & $\begin{array}{c}\text { Std. Error of } \\
\text { the Estimate }\end{array}$ \\
\hline 1 &, $906^{a}$ &, 820 &, 814 & 163,47237 \\
\hline
\end{tabular}

a. Predictors: (Constant), Hari

Gambar 3. Model Summary

Keterangan :

Gambar diatas mengungkapkan besarnya nilai interaksi (R) yaitu sebanyak 0,906. Dari keluaran tadi didapatkan koefisien determinasi (R Square) sebanyak 0,820, yang memiliki maksud bahwa imbas variabel bebas (Hari) pada variabel terikat (Kasus Aktif) yaitu sebanyak $82 \%$.

\begin{tabular}{|c|c|c|c|c|c|c|}
\hline \multicolumn{7}{|c|}{ ANOVA ${ }^{b}$} \\
\hline & & $\begin{array}{c}\text { Sum of } \\
\text { Squares }\end{array}$ & df & Mean Square & $\mathrm{F}$ & Sig. \\
\hline \multirow[t]{3}{*}{1} & Regression & 127288,929 & 1 & 127288,929 & 1,962 & $.185^{a}$ \\
\hline & Residual & 843268,405 & 13 & 64866,800 & & \\
\hline & Total & 970557,333 & 14 & & & \\
\hline
\end{tabular}

Gambar 4. Anova

Keterangan :

Dari hasil tadi dapat dilihat jika nilai $\mathrm{F}$ hitung = 1,962 dengan tingkat signifikansi sebanyak 0.185.

DOI: $10.52362 /$ jisamar.v5i2.420

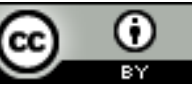

Ciptaan disebarluaskan di bawah Lisensi Creative Commons Atribusi 4.0 Internasional. 


\begin{tabular}{|c|c|c|c|c|c|c|}
\hline \multicolumn{7}{|c|}{ Coefficients ${ }^{a}$} \\
\hline \multirow{2}{*}{\multicolumn{2}{|c|}{ Model }} & \multicolumn{2}{|c|}{ Unstandardized Coefficients } & $\begin{array}{c}\text { Standardized } \\
\text { Coefficients }\end{array}$ & \multirow[b]{2}{*}{$t$} & \multirow[b]{2}{*}{ Sig. } \\
\hline & & $B$ & Std. Error & Beta & & \\
\hline \multirow[t]{2}{*}{1} & (Constant) & 37302,238 & 138,388 & & 269,549 & .000 \\
\hline & Hari & $-21,321$ & 15,221 &,- 362 & $-1,401$ &, 185 \\
\hline
\end{tabular}

a. Dependent Variable: Kaus Aktif

Gambar 5. Coefficients

Keterangan :

Diketahui nilai Constanta (a) sebanyak 37302,238, sedangkan nilai Hari (b / koefisient regresi) sebanyak 21,321, jadi persamaan garis lurusnya dapat ditulis:

$\mathrm{Y}=\mathrm{a}+\mathrm{bX}$

$\mathrm{Y}=37302,238+(-21,321) \mathrm{X}$

Persamaan tadi bisa diartikan :

1. Konstanta sebanyak 37302,238, memiliki arti bahwa nilai tetap variabel Kasus Aktif merupakan sebanyak 37302,238

2. Koefisien regresi $X$ sebanyak -21,321 menyatakan jika setiap kenaikan $1 \%$ nilai Hari, maka nilai Kasus Aktif naik sebanyak -21,321. Koefisien regresi tadi bernilai negatif, jadi bisa diartikan bahwa variabel $\mathrm{X}$ memiliki arah pengaruh terhadap Y yaitu negatif.

\section{Penetapan Keputusan pada Uji Regresi Sederhana}

1. Dari nilai signifikansi : berdasarkan tabel Coeficient dapat didapatkan nilai signifikansi sebanyak $0.185>$ 0.05, jadi bisa disimpulkan bahwa variabel Hari $(\mathrm{X})$ memiliki pengaruh (pengaruh negatif) pada variabel Kasus Aktif (Y).

2. Dari nilai $\mathrm{t}$; diketahui nilai sebesar $-1,401<2160$, jadi bisa disimpulkan bahwa variabel Hari (X) memiliki pengaruh negatif terhadap variabel Kasus Aktif (Y).

Tambahan : cara mencari

$=(\mathrm{a} / 2: \mathrm{n}-\mathrm{k}-1)$

$=(0,05 / 2: 13)$

$=2160$ 


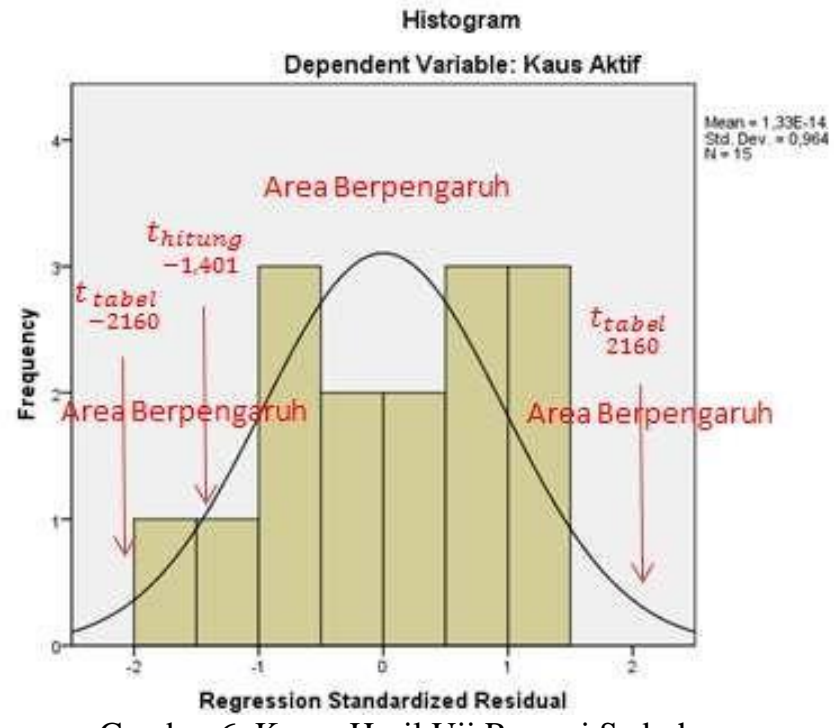

Gambar 6. Kurva Hasil Uji Regresi Sederhana

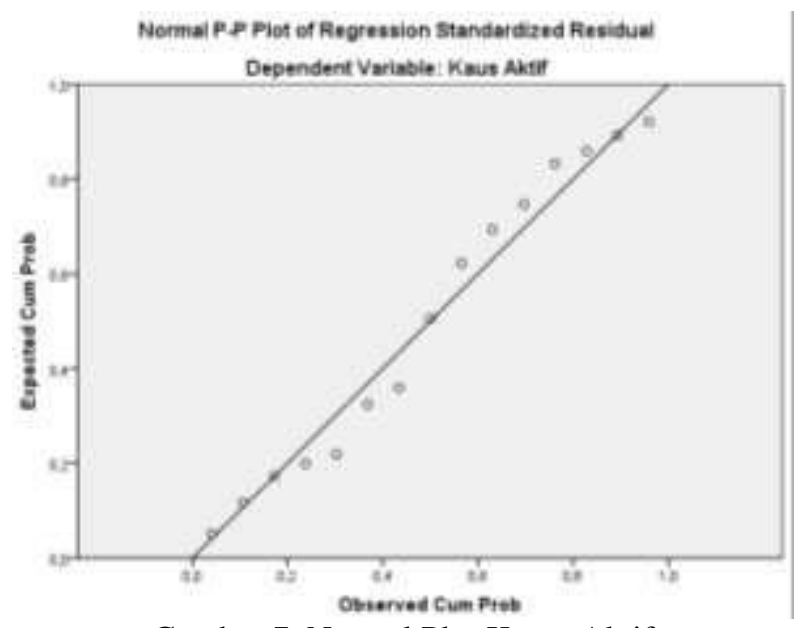

Gambar 7. Normal Plot Kasus Aktif

Tabel 3. Hasil Perhitungan menggunakan metode backpropagation dan regresi linear

\begin{tabular}{|l|l|l|}
\hline Waktu & Prediksi Backpropagation & Prediksi Regresi \\
\hline $16-9-2020$ & 63350 & 56779 \\
\hline $17-9-2020$ & 63345 & 57737 \\
\hline $18-9-2020$ & 63348 & 58695 \\
\hline $19-9-2020$ & 63353 & 59653 \\
\hline $20-9-2020$ & 63351 & 60611 \\
\hline $21-9-2020$ & 63353 & 61569 \\
\hline $22-9-2020$ & 63355 & 62527 \\
\hline $23-9-2020$ & 63358 & 63485 \\
\hline $24-9-2020$ & 63372 & 64443 \\
\hline $25-9-2020$ & 63368 & 65401 \\
\hline
\end{tabular}

DOI: $10.52362 /$ jisamar.v5i2.420

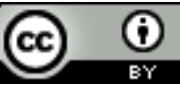

Ciptaan disebarluaskan di bawah Lisensi Creative Commons Atribusi 4.0 Internasional. 


\begin{tabular}{|l|l|l|}
\hline $26-9-2020$ & 63370 & 66359 \\
\hline $27-9-2020$ & 63374 & 67317 \\
\hline $28-9-2020$ & 63370 & 68275 \\
\hline $29-9-2020$ & 63360 & 69234 \\
\hline $30-9-2020$ & 63347 & 70192 \\
\hline
\end{tabular}

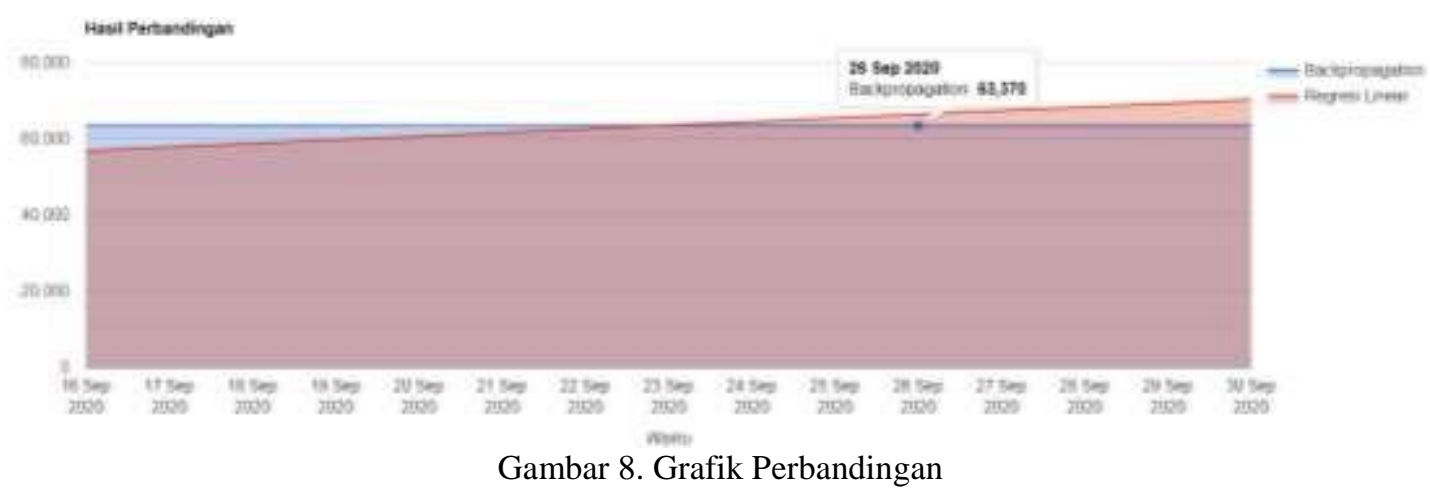

\section{KESIMPULAN DAN SARAN}

\subsection{Kesimpulan}

Setelah penjelasan serta penjabaran pada bab sebelumnya, dapat dijelaskan bahwa:

1. Semakin banyak data historis kasus aktif yang dipakai untuk melatih model jaringan dapat menghasilkan taraf pengenalan terhadap pola kasus aktif menjadi lebih baik yang menjadikan terhadap kemampuan model JST dalam memperkirakan penambahan kasus aktif semakin baik.

2. Secara umum hasil prediksi kasus aktif dengan Backpropagation memberikan hasil peningkatan dan penurunan yang tidak terlalu signifikan.

3. Secara umum hasil prediksi kasus aktif dengan Regresi Linear menunjukan bahwa penambahan kasus untuk tiap harinya mengalami pertambahan kasus aktif.

4. Parameter parameter yang diinputkan didalamnya dapat mempengaruhi kinerja dari algoritma backpropagation.

5. Dari nilai signifikansi : berdasarkan tabel Coeficient didapatkan nilai signifikansi sebanyak $0.185>0.05$, jadi bisa disimpulkan bahwa variabel Hari $(\mathrm{X})$ memiliki pengaruh (pengaruh negatif) terhadap variabel Kasus Aktif(Y).

6. Dari nilai t ; diketahui nilai sebanyak $-1,401<2160$, jadi bisa disimpulkan bahwa variabel Hari $(\mathrm{X})$ memiliki pengaruh negatif terhadap variabel Kasus Aktif(Y)

7. Dari hasil simulasi Matlab dengan tiga fungsi pelatihan yaitu traincgb didapatkan nilai rata-rata error yaitu sebesar 0,017107, dengan fungsi pelatihan traingd didapatkan nilai rata-rata error sebesar -0,55116 serta fungsi pelatihan traingdx didapatkan nilai rata-rata error sebesar -3,82202 sehingga dapat disimpulkan fungsi pelatihan yang paling konvergen yaitu fungsi pelatihan terhadap traingdx dengan nilai rata-rata error paling kecil.

\subsection{Saran}

Saran yang bisa disampaikan pada peneliti yang akan melanjutkan dan mengembangkan penelitian ini adalah :

1. Penelitian ini perlu dikembangkan lagi agar bisa menambah akurasi model jaringan dalam melakukan perkiraan kasus aktif jangka pendek maupun jangka panjang, diantaranya dengan menambah data input sebagai data training. Data yang diambil di penelitian ini mengambil data kasus aktif yang digunakan adalah data selama lima belas hari di bulan Agustus dengan data kasus aktif saja. Sehingga diharapkan hasil penelitian akan mendapatkan akurasi lebih baik lagi.

2. Penelitian ini masih dapat dikembangkan dengan menambahkan studi kasus data meninggal serta data yang sembuh. 
Journal of Information System, Applied, Management, Accounting and Research. http://journal.stmikjayakarta.ac.id/index.php/jisamar, jisamar@stmikjayakarta.ac.id , jisamar2017@gmail.com e-ISSN: 2598-8719 (Online), p-ISSN: 2598-8700 ( Printed), Vol. 5 No.2 Mei 2021

\section{REFERENASI}

[1] W. H. Organization, "Q\&A on coronaviruses (COVID-19),” 2020. .

[2] R. Widiyani, "Latar Belakang Virus Corona, Perkembangan hingga Isu Terkini," Retrieved from detikNews, 2020. .

[3] I. Kottasova, "Coronavirus Lockdowns: 24 Hours of Confusion Around the World," CNN Health, 2020. .

[4] J. J. Siang, "Jaringan syaraf tiruan dan pemrogramannya menggunakan Matlab," Penerbit Andi, Yogyakarta, 2005.

[5] F. S. D. Arianto and N. P, "Prediksi Kasus COVID-19 di Indonesia Menggunakan Metode Backpropagation dan Fuzzy Tsukamoto," J. Teknol. Inf., vol. 4, no. 1, pp. 120-127, 2020.

DOI: $10.52362 /$ jisamar.v5i2.420 


\section{SURAT PERNYATAAN KEASLIAN NASKAH \\ (Statement of Authenticity of Status)}

Yang bertanda tangan di bawah ini menyatakan bahwa:

Judul naskah:

PREDIKSI KASUS COVID-19 DI INDONESIA MENGGUNAKAN METODE BACKPROPAGATION DAN REGRESI LINEAR

Penulis:

1. Nama : Heri Purwanto_ e-mail : Heripurwanto@lpkia.ac.id

2. Nama : Wahyudin e-mail : 16061056wahyudin@gmail.com

Nama dan alamat penulis 1 (perwakilan) untuk korespondensi:

Nama : Heri Purwanto S.T.,M.M.,MT

Alamat : STMIK Politeknik LPKIA Bandung, Komplek Griya Pasir Honje No. 30 Rt 7 Rw 2, Kel. Padasuka Kec. Cimenyan Kab. Bandung

Telp. : 082216643571

e-mail : Heripurwanto@1pkia.ac.id

- Jurnal/Artikel tersebut di atas merupakan naskah asli, hasil karya penulis, dan bukan merupakan plagiat dari artikel atau karya ilmiah orang lain.

- Jurnal/Artikel tersebut di atas belum pernah dipublikasikan atau tidak sedang diajukan untuk dimuat pada jurnal atau media lainnya.

- Apabila kemudian hari pernyataan ini tidak benar, maka penulis bersedia menerima sanksi dengan peraturan perundang-undangan yang berlaku.

Penulis 1.

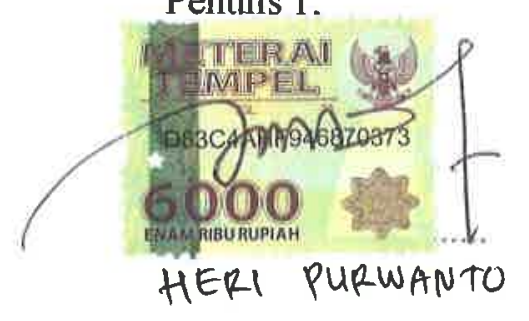

Penulis 2,

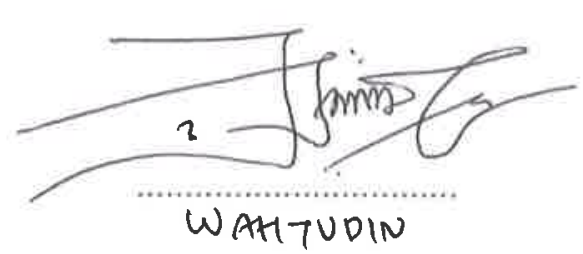

Note : * Hapus yang tidak perlu (disesuaikan) 


\section{SURAT PERNYATAAN KESEDIAAN PUBLIKASI \\ (Statement of Publication Availability)}

Saya yang bertandatangan di bawah ini :

Nama (Penulis 1) : Heri Purwanto, S.T.,M.M.,M.T

Asal Institusi

: STMIK LPKIA Bandung"

No.Telepon

: 082216643571

Email

: Heripurwanto@lpkia.ac.id

Bersama ini saya menyatakan BERSEDIA untuk publikasi paper dengan judul :

PREDIKSI KASUS COVID-19 DI INDONESIA MENGGUNAKAN METODE

BACKPROPAGATION DAN REGRESI LINEAR

Di.JISAMAR (Joumal of Information System, Applied, Management, Accounting and Research) : Vol

5 No 2 Tahun 2021

Saya menyatakan bahwa karya ilmiah tersebut di atas terbebas dari unsure plagiarism dan publikasi ganda (belum pernah dipublikasikan ke media manapun).Serta tidak akan diterbitkan ulang pada Jurnal/Buku dan atau majalah lainnya.

Saya juga bersedia membayar biaya publikasi pada JISAMAR (Journal of Information System, Applied, Management, Accounting and Research) sesuai ketentuan dan aturan yang berlaku**).

Demikian surat pernyataan ini dibuat dalam keadaan sehatwal'afiat tanpa paksaan dari pihak manapun dan agar dapat dipergunakan sebagaimana mestinya.

Bandung, 03, Mei, 2020

Yang MembuatPernyataan

Penulis 1.

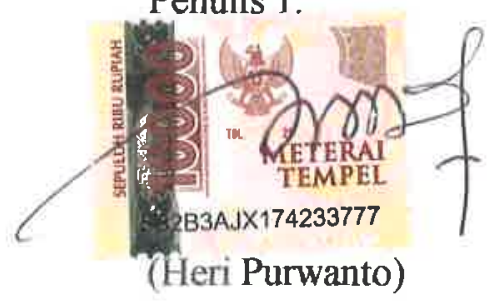

Penulis 2,

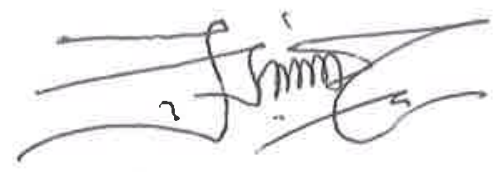

(Wahyudin)

Note :

* :Coret yang tidak sesuai(disesuaikan)

**: Dibayar setelah artikel dinyatakan SLAP PUBLISH. Biaya publikasi bisa dilihat di web JISAMAR 